\title{
Investor's Behavior and Mutual Fund - A Study in Cuttack City
}

\author{
Aditya Prasad Sahoo \\ Research Scholar, KIIT University, Bhubaneswar, Odisha, India
}

\section{OPEN ACCESS}

Manuscript ID:

COM-2020-08043341

Volume: 8

Issue: 4

Month: October

Year: 2020

E-ISSN: 2582-6190

Received: 10.08.2020

Accepted: 20.09.2020

Published: 01.10.2020

Citation:

Sahoo, Aditya Prasad. "Investor's Behavior and Mutual Fund - A Study in Cuttack City." ComFin Research, vol. 8, no. 4, 2020, pp. 18-22.

\section{DOI:}

https://doi.org/10.34293/ commerce.v8i4.3341

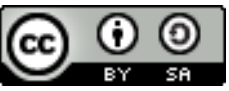

This work is licensed under a Creative Commons Attribution-ShareAlike 4.0 International License

\begin{abstract}
In the fastest-growing economy of India, the mutual fund industry puts an emerging footprint in economic growth and development. Mutual funds create a simple and viable path for saving and investment. The mutual fund includes various investment benefits like liquidity, timely return, fund diversification, widespread analysis monetary allocation vis-à-vis a full disclosure of fund management. There are various investment products available for investment in the financial market. However, all these investment products must be able to meet an investor's expectations? Hence to know the investor's perception and expectation, it is necessary to study the implications of mutual funds from a unique perspective. This paper explains how different factors are affecting an individual's perception of mutual funds. As per the findings, individuals are more inclined to traditional investment than an investment in a mutual fund. Those who have invested in mutual funds, most of them were selected equity option and Systematic investment plan or SIP. Another finding is that investors don't want to analyze the inherent risks associated with the investment and need their fund managers and broker's advice.
\end{abstract}

Keywords: Investor, Profitability, Safety, Investment and Mutual Fund

\section{Introduction}

The main theme of Mutual fund companies is the collection of funds from various sources and mobilizes the same efficiently to achieve the investment objective of the corresponding investors. There are various financial products and schemes available in Mutual funds investment. However, two main categories where investment is made are equity and debt. Meanwhile, to invest in these two categories, investors need a proper understanding of investment concepts and skills to make the investment decision good enough to get the desired return. But in practice, investors largely depend on Mutual fund institutions due to their poor skill and shortage of time. The mutual fund helps in associating time and skill limitations. Mutual funds include a group of proficient and skilled persons who have very depth knowledge of investment risk and return. They utilize and mobilize the investor's fund in the best possible manner by delivering a maximum return per their investment; mutual funds issue units to the investors. Investors' profit and loss are depend on their proportion of investment.

\section{Chart of Mutual Fund Operation}

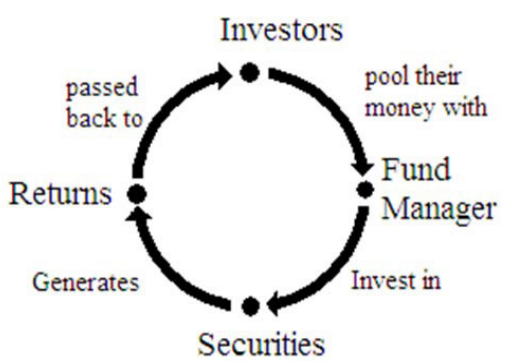


Table 1: Bank and Mutual Fund - A Comparison

\begin{tabular}{|l|l|l|}
\hline \multicolumn{1}{|c|}{ Factors } & \multicolumn{1}{c|}{ Bank } & Mutual Fund \\
\hline Returns & Low & Better \\
\hline $\begin{array}{l}\text { Administrative } \\
\text { Exp. }\end{array}$ & High & Low \\
\hline Risk & Low & Moderate \\
\hline $\begin{array}{l}\text { Investment } \\
\text { Options }\end{array}$ & Less & More \\
\hline Network & High Penetration & $\begin{array}{l}\text { Low but } \\
\text { Improving }\end{array}$ \\
\hline Liquidity & At a Cost & Better \\
\hline $\begin{array}{l}\text { Quality of } \\
\text { Assets }\end{array}$ & Not Transparent & Transparent \\
\hline Guarantee & $\begin{array}{l}\text { Maximum Rs. } \\
1,00,000 \text { on deposits }\end{array}$ & None \\
\hline
\end{tabular}

\section{Review of Literature}

Singh and Jha, 2015, piloted a study where they found that investors are attracted to the Mutual fund investment due to its income capability, return viability, liquidity, and safety. However, they lack knowledge of SIP investment. They are also consider other investment avenues before investment in Mutual funds.

Desigan et al., 2014, found in their study that women investors are less interested foe investment in Mutual funds because of their poor money management skills, ignorant towards investment procedure, lack skills of stock market operation, and unaware of market information. Women are good savers. But due to the low level of awareness on various Mutual fund products, they are avoiding investment in Mutual funds.

Ramamurthy and Reddy, 2010, piloted a study to investigate current drifts in the mutual fund industry and lure a decision that the core paybacks for small investors' attributable to competent management, diversification of investment, tranquil supervision, positive feasibility of return, liquidness of investment, limpidity, flexibility, low cost, broad selectivity, and an appropriate guideline-directed by SEBI. They also steered different entry and exit policies of Mutual fund institutions and other available schemes for investment in various avenues through Mutual funds.
Anand and Murugaiah, 2008, were pointed out deliberate practices in financial services marketing. As per their observance, the Mutual fund sector needs new tactics to survive in this competitive economy and must look after an efficient operation or fund management. They have to create a new strategic plan to market their products to meet the challenges coming from the global competitive environment.

\section{Objectives of the Study}

The main goal of this paper is to know the perception, awareness, and behavior of investors towards Mutual funds in Cuttack city to find their preferred pattern of investment.

1. To know the investor's preference towards different investment avenues.

2. To know their knowledge in risk management and analysis in investment.

3. To find out their switching pattern of investment and

4. To get information on their mode of investment in Mutual funds.

\section{Research Methodology}

This study is based on both primary and secondary sources of data. Primary sources of data include a sampling of 150 respondents from Cuttack city. Respondents are segregated on the basis demographical perspective. Subsequently, to collect the desired information of their behavior, a properly structured questionnaire has been prepared and distributed among the individuals. Similarly, secondary sources of data include various newspapers, journals, magazines and books, reports of AMFI, RBI, and internet sources. All the data collected from questionnaires are concurrently processed, categorized, and interpreted by following statistical analysis.

\section{Hypothesis}

1. Investors are preferred to invest in Mutual funds because they find it safe and profitable.

2. Investors are aware of investment risk in Mutual funds.

3. Investors are preferred to invest in short term schemes of Mutual funds to get relief from tax trouble. 
4. Investors do switchover from one scheme to another to get more profits.

5. Investors hardly face loss in Mutual fund investment.

\section{Results and Discussion}

From the analysis, it is found that 130 individuals choose. Mutual funds for investment and others are chosen alternative avenues of investment. Respondents were asked to give their investment preferences on different available investment avenues such as LIC, Currency holdings, Public Provident Fund, Fixed deposits in a bank, Postal saving schemes, UTI, Real estate, Equity investment, and Mutual funds. In the questionnaire, the rank was provided from 1 to 9 for their preferences of investment towards various instruments. They were asked to select their choice of instruments for investment by providing ticks from high rank ' 1 ' too low rank ' 9 '. As per their investment preferences following table has been prepared.

Table 2: Investments made by Investors in Different Investment Avenues

\begin{tabular}{|c|c|c|c|c|c|c|c|c|c|}
\hline & LIC & C.H. & PPF & FD & PSS & GOLD & MF & R.E. & EQUITY \\
\hline Sample & 150 & 150 & 150 & 150 & 150 & 150 & 150 & 150 & 150 \\
\hline Mean & 5.18 & 4.08 & 4.36 & 6.25 & 4.89 & 6.18 & 4.12 & 5.70 & 3.87 \\
\hline Ranking & 4 & 9 & 6 & 1 & 5 & 2 & 7 & 3 & 8 \\
\hline
\end{tabular}

From the above table, it is found that fixed deposit in banks remains a high level of investment preference by the individuals in Cuttack city. Gold comes second. Real estate in the third position, LIC in the fourth one, Post office saving is at fifth, PPF is at sixth, Mutual fund comes seven, and last one equity is at ninth. This shows that level of awareness towards Mutual funds in the city is very low. Investors' perception of investment is completely depend up on safety, riskless return, and profitability.
We can say that investors in the city choose safety over a higher return. They do not want to take a risk; even the investment law is based on the higher the risk higher is the return.

Similarly, to study their investment preferences based on four modes like Safety, Liquidity, Consistency, taxation, Profitability Likert scale of measurement has been used. They were asked to give their choices as per the five modes of investment. Median statistics have been used to find the results.

Table 3: Preference of Investment based on Different Modes

\begin{tabular}{|c|c|c|c|c|c|c|c|c|}
\hline Variables & GOLD & F.D. & EQUITY & PSS & M.F. & LIC & R.E. & PPF \\
\hline Safety & 4 & 5 & 1 & 5 & 1 & 5 & 5 & 5 \\
\hline Liquidity & 5 & 4 & 3 & 2 & 2 & 2 & 1 & 1 \\
\hline Consistency & 3 & 5 & 1 & 4 & 1 & 3 & 4 & 3 \\
\hline Taxation & 1 & 1 & 2 & 4 & 4 & 4 & 1 & 3 \\
\hline Profitability & 4 & 3 & 5 & 1 & 5 & 1 & 5 & 2 \\
\hline Total & 17 & 18 & 12 & 16 & 14 & 15 & 16 & 14 \\
\hline
\end{tabular}

From the above analysis, it is found that in the city, individuals are more inclined to bank deposits and gold. Real estate also positive avenues of investment from the investors' point of view. Considering all the variables, it is clear that investor's perception of Mutual fund investment is in the nascent stage. They prefer safety, liquidity, profitability, and consistency over higher returns.

Table 4: Knowledge and Risk Analysis of Investors

\begin{tabular}{|c|c|c|c|c|c|c|}
\hline & \multicolumn{3}{|c|}{ Knowledge } & \multicolumn{3}{c|}{ Risk Analysis } \\
\hline & Frequency & \% & C.P. & Frequency & \% & C.P. \\
\hline Yes & 90 & 69.23 & 69.23 & 55 & 42.30 & 42.30 \\
\hline No & 40 & 30.77 & 100 & 75 & 57.70 & 100 \\
\hline Total & 130 & 100 & & 130 & 100 & \\
\hline
\end{tabular}


From the about table, it is clear that $69 \%$ of investors know the risk in investment. It is clear that investors are aware of the risk in Mutual funds investment, and it is representing their risk-averse attitude towards Mutual funds. Subsequently, when questions were asked on risk analysis while investment, the finding is very surprising. While $69 \%$ of investors are aware of risk available in investment, only $42 \%$ have the skill to calculate or evaluate the risk in investment.

Table 5: Analysis of Mode of Investment and Switchover Reasons

\begin{tabular}{|l|l|c|c|c|}
\hline & & Yes & No & Total \\
\hline \multirow{2}{*}{$\begin{array}{l}\text { Safety } \\
\text { Mode of } \\
\text { Investment }\end{array}$} & Frequency & 120 & 10 & 130 \\
\cline { 2 - 5 } & $\%$ & 92.30 & 7.70 & 100 \\
\cline { 2 - 5 } $\begin{array}{l}\text { Profitability } \\
\text { in }\end{array}$ & C.P. & 92.30 & 100 & \\
\cline { 2 - 5 } Investment & $\%$ & 112 & 18 & 130 \\
\cline { 2 - 5 } & C.P. & 86.15 & 13.85 & 100 \\
\hline \multirow{3}{*}{$\begin{array}{l}\text { Switching } \\
\text { Reason }\end{array}$} & Frequency & 94 & 100 & \\
\cline { 2 - 5 } & $\%$ & 72.30 & 27.70 & 100 \\
\cline { 2 - 5 } & C.P. & 72.30 & 100 & \\
\hline
\end{tabular}

From the above table, it is clear that investors believe that Mutual fund is the proper medium of investment in the stock market. $92 \%$ of the city think that Mutual fund is a reliable channel to participate in the stock market. Similarly, their point of view towards profitability in Mutual fund investment looks positive. $86 \%$ of individuals know that Mutual fund investment is profitable. As per their opinion, the return in Mutual fund is high. So it will maximize their return and profitability. Apart from the mode of investment, when questions were asked on why they want to move from one scheme to another, their answer came into two categories. One is profitability, and another one is safety. Some investors switchover from one scheme to another due to earn high return or profitability, and some are due to safety. From the table, it is found that $72 \%$ of respondents switchover from one scheme to another to earn more profit. At the same time, $27 \%$ of respondents chose safety over profitability.

Subsequently, to study the investor's nature of holding funds in different Mutual funds schemes, questionnaires were prepared, including four types of available funds for investment. Those are Equity Mutual fund, Debt Mutual fund, and Hybrid Mutual fund. Questions were also asked on a period of investment. Investors' nature of holding and period of holding can be interpreted from the below table.

Table 6: Nature and Period of Holding

\begin{tabular}{|c|c|c|c|c|}
\hline \multicolumn{5}{|c|}{ Nature of Holding Funds } \\
\hline & Equity & Debt & Hybrid & Total \\
\hline Frequency & 72 & 38 & 20 & 130 \\
\hline$\%$ & 55.38 & 29.24 & 15.38 & 100 \\
\hline C.P. & 55.38 & 84.62 & 100 & \\
\hline \multicolumn{5}{|c|}{ Period of Holding } \\
\hline & $\begin{array}{c}\text { Upto } 1 \\
\text { Year }\end{array}$ & $\begin{array}{c}\text { Upto } 3 \\
\text { Year }\end{array}$ & $\begin{array}{c}\text { Upto } 5 \\
\text { Year }\end{array}$ & Total \\
\hline Frequency & 29 & 77 & 24 & 130 \\
\hline$\%$ & 22.31 & 59.25 & 18.44 & 100 \\
\hline C.P. & 22.31 & 81.56 & 100 & \\
\hline
\end{tabular}

From the above table, it is clear that $72 \%$ of individuals want to invest in Equity Mutual fund, $38 \%$ of individuals want to invest in Debt Mutual fund, and 20\% individuals went for Hybrid Mutual fund for investment. As per the study investors,' number for investment in Equity-based Mutual fund is high. Likewise, when questions were asked on period of holding, $22 \%$ of individuals want to invest in schemes up to 1 year, $59 \%$ want to invest in schemes available for up to 3 years, and $18 \%$ want to invest in schemes up to 5 years. This is clear investor's preference towards schemes which are for 1 to 3 years is very high as a comparison to schemes for less than one year and five years.

\section{Suggestions}

Investors should evaluate risk in Mutual funds schemes before giving their hard-earned money for investment. They can go for a professional analysts to know which fund is good for investment in line with safety, liquidity, and profitability. Apart from this, they must open their instinct while investing by analyzing other factors like market sentiments, reliability of market information, funds volatility to make the investment safer vis-a-vis profitable. It is also desirable for the investors that they should go for proper diversification, regular risk analysis, and must-read business news, periodicals to grasp a good 
understanding of market conditions. While investing in Mutual funds, the investment amount must be small, as Mutual funds are subject to market risks. A smooth, consistent investment with a small amount will lead to $\mathrm{p}$ balanced management of funds. Similarly, a strong opinion of the author towards Mutual funds investment is that all individual must keep their certain part of the money in those Mutual fund schemes which are liquid. This will help the investors to meet their contingencies as and when required by them.

\section{Conclusion}

As per the study, preferences towards Mutual fund and investment is still very low. No doubt, individuals are aware of the fact that Mutual fund return is high and can give them profitable investment opportunities. But they still leave in the traditional mode of investments like gold and bank deposits. The foremost clue behind this is fear of risk, uncertainty, and market volatility. Investors in the city prefer the safety mode of investment rather than a profitable mode of investment. All they are believe in safe investment with a consistent return. However, awareness must be created on investment in Mutual funds. Even the risk in investment is high, it can be mitigated through proper consultation, analysis, and diversification to maximize the return.

\section{References}

Agrawal, G.D. "Mutual Fund and Investors Interest." The Journal for Corporate Professionals, vol. 22, no. 1, 1992, pp. 23-24.

Atmaramani, K.N. "Mutual Funds: The Best Avenue for Investment." Chartered Secretary, vol. 31, no. 1, 2001, pp. 9-11.
Banerjee, Arindam. "Mutual Funds: Wealth Creation through Systematic Investment Plans." ICFAI Portfolio Organiser, pp. 53-58.

Bhayani, J., and G. Patidar. "An Empirical Analysis of Performance Evaluation of Mutual Fund Schemes in India." ICFAI Reader, 2006, pp. 15-24.

Dhar, Satyajit. "Mutual Funds in India - A Close Look." Finance India, 1994, pp. 675-679.

Ganesan, S., and J. Raja. "Mutual Funds, the Millennium Strategy." The Journal of the All India Management Association, vol. 39, no. 10,2000 , pp. $42-47$.

Kaur, Inderjit, and K.P. Kaushik. "Determinants of Investment Behaviour of Investors towards Mutual Funds." Journal of Indian Business Research, vol. 8, no. 1, 2016, pp. 19-42.

Liu, Xiangbo, et al. "Investor Cash Flow and Mutual Fund Behavior." Manchester School, vol. 83, no. 1,2015 , pp. 56-71.

Mehta, Rajan. "Indian Mutual Fund Industry: Challenging Issues." Chartered Financial Analyst, 2003, pp. 32-33.

Pandya, Aabhas. "Have Mutual Funds passed the Test?" ICFAI Reader, 2001, pp. 50-51.

Rajarajan. "Determinants of Portfolio Choice of Individual Investors." The Indian Economic Journal, vol. 50, 2003, pp. 81-84.

Rajarajan. "Stages in Life Cycle and Investment Pattern." The Indian Journal of Commerce, vol. 51, 1998, pp. 27-36.

Salam, Abdus, and Umma Kulsum. "Savings Behaviour in India: An Empirical Study." The Indian Economic Journal, vol. 50, 2003, pp.77-80.

\section{Author Details}

Aditya Prasad Sahoo, Ph.D., Research Scholar, KIIT University, Bhubaneswar, Odisha, India,

Email ID: adityasahoo007@gmail.com. 